\title{
Epidemiological Profile of Surgically-Treated Peripheral-Nerve Diseases
}

\section{Perfil epidemiológico das doenças de nervos periféricos tratadas cirurgicamente}

\author{
Helen Kerlen Bastos Fuzari ${ }^{1,2}$ Armèle Dornelas de Andrade ${ }^{2}{ }^{\circledR}$ Renata Janaina Pereira de Souza ${ }^{2}(1)$ \\ Silvya Nery Bernardino ${ }^{3}$ Fernando Henrique Moraes de Souza ${ }^{4}$ Antonio Sarmento $^{2}{ }^{\circledR}$ \\ Daniella Araújo de Oliveira ${ }^{1,2}$
}

1 Programa de Neuropsiquiatria e Ciências do Comportamento (POSNEURO), Universidade Federal de Pernambuco (UFPE), Recife, PE, Brazil

2 Department of Physiotherapy, Universidade Federal de Pernambuco (UFPE), Recife, PE, Brazil

3 Hospital Getúlio Vargas, Recife, PE, Brazil

${ }^{4}$ Hospital da Restauração, Recife, PE, Brazil

Arq Bras Neurocir 2021;40(3):e215-e221.
Address for correspondence Helen Kerlen Bastos Fuzari, Departmento de Fisioterapia, Universidade Federal de Pernambuco, Av. Jornalista Aníbal Fernandes s/n - Cidade Universitária, Recife, PE, 50740-560, Brazil (e-mail: helen.fisio@uol.com.br).

\begin{abstract}
Objective To outline the epidemiological profile of surgical patients treated at the peripheral-nerve outpatient clinic of a public hospital in the state of Pernambuco, Brazil, from 2008 (the year this service was implemented in the hospital) to 2016.

Material and Methods A cross-sectional study with data collection from the medical records. A descriptive analysis was performed with the qualitative variables presented as relative and absolute frequencies, and the quantitative variables, as means and standard deviations. The studied variables were gender, age, diagnosis, and surgical techniques.

Results In total, 506 medical records were analyzed. Of these, 269 were of male patients (53\%), and 238 were of female patients (46\%). The age of the sample ranged from 5 to 84 years ( $41 \pm 14$ years). The most prevalent diagnoses were: carpal tunnel syndrome (38.9\%) followed by traumatic brachial plexus injury (33.2\%). The first diagnosis was more frequent among women, while the second, among men. This

Keywords

- epidemiology

- brachial plexus

- carpal tunnel syndrome collaborates with the predominant findings of upper-limb lesions (91\%), in which men accounted for $52,75 \%$ (244) and women, for $47,25 \%$ (217).

Conclusion The present study provided relevant information regarding the reality of peripheral-nerve surgeries performed at a public hospital in the state of Pernambuco, Brazil. Public health issues increasingly require the continuity of public policies and government incentive.
\end{abstract}

received

May 13, 2020

accepted

August 24, 2020

published online

November 26, 2020
DOI https://doi.org/ 10.1055/s-0040-1719001. ISSN 0103-5355. (c) 2020. Sociedade Brasileira de Neurocirurgia. All rights reserved. This is an open access article published by Thieme under the terms of the Creative Commons Attribution-NonDerivative-NonCommercial-License, permitting copying and reproduction so long as the original work is given appropriate credit. Contents may not be used for commercial purposes, or adapted, remixed, transformed or built upon. (https://creativecommons.org/ licenses/by-nc-nd/4.0/)

Thieme Revinter Publicações Ltda., Rua do Matoso 170, Rio de Janeiro, RJ, CEP 20270-135, Brazil 


\section{Resumo}

Palavras-chave
- epidemiologia
- plexo braquial
- síndrome do túnel do
carpo

Objetivo O presente estudo buscou delinear o perfil epidemiológico dos pacientes cirúrgicos atendidos no ambulatório de nervos periféricos de um hospital público de Pernambuco no período de 2008 (ano de implantação deste serviço no hospital) a 2016.

Material e métodos Estudo transversal com coleta de dados em prontuários. Foi realizada análise descritiva, com as variáveis qualitativas apresentadas como frequências relativas e absolutas, e as variáveis quantitativas numéricas, como médias e desvios padrão. As variáveis estudadas foram sexo, idade, diagnóstico, e técnicas cirúrgicas.

Resultados No total, 506 prontuários foram analisados, sendo 269 de pacientes homens (53\%) e 238 de pacientes mulheres (46\%). A faixa etária variou de 5 a 84 anos (41 \pm 14 anos). Os diagnósticos mais prevalentes foram: síndrome do túnel do carpo (38\%), seguida por lesão traumática do plexo braquial (33\%). O primeiro diagnóstico foi mais frequente entre as mulheres, e o segundo, entre os homens. Isto colabora com os achados predominantes das lesões dos membros superiores (91\%), em que os homens representaram $52.75 \%$ (244), e as mulheres, $47.25 \%$ (217).

Conclusão $O$ presente estudo forneceu informações relevantes sobre a realidade das cirurgias de nervos periféricos realizadas em um hospital público em Pernambuco. Tais problemas de saúde pública precisam cada vez mais da continuidade das políticas públicas e do incentivo do governo.

\section{Introduction}

Peripheral-nerve lesions have been extensively studied in recent years; ${ }^{1}$ however, the diagnosis and treatment are still a challenging problem that requires an appropriate approach, adequate electrodiagnostic and imaging studies, and adequate time for early diagnosis. ${ }^{2}$

Peripheral-nerve diseases range from traumatic lesions (that is, stretching, avulsion, crushing, or compression) to degenerative-infectious conditions. Once damaged, the peripheral nerves may suffer an interruption in the transmission of signals, affecting limb function directly through sensory and motor deficits, or both. In some cases, compression may lead to a better prognosis (such as in cases of radial nerve compression), or surgical interventions, such as in more severe cases (compartmental syndromes in which the nerve is compressed considerably, for example). ${ }^{3}$ Moreover, the incidence of individuals with injury to the brachial plexus after automobile accidents has increased considerably, and is considered a public health problem, since it aggravates hospitalization costs and treatments, as well as the labor licenses for those in full working activity. ${ }^{4}$

Rehabilitation after nerve decompression takes time, since it depends on axon regeneration ( $\sim 1 \mathrm{~mm}$ to $5 \mathrm{~mm}$ /day in adults). ${ }^{5}$ It should also be noted that many factors are determinants in rehabilitation, such as age, cause of the injury, the degree of compression, the time of onset of the problem, and the most appropriate surgery for each case. Notwithstanding, in most cases, referral to a specialist is time-consuming, making some types of procedures impossible. $^{6}$ In this sense, outpatient clinics must present sufficient subsidies for accurate semiology and establish the best course of action for each patient. Nevertheless, there is still a lack of complementary tests and continuous rehabilitation to guarantee the success of the procedure in hospital and clinical services.

It is also important to point out that peripheral-nerve outpatient clinics in Brazil are still in development and expansion; thus, a lot must improve. ${ }^{7}$ Although the state of Pernambuco (located in Noertheastern Brazil) has one of the main reference centers for peripheral nerve surgery in the Northeast, there is no literature describing its reality. Thus, the present study aimed to trace an epidemiological profile of patients undergoing peripheral-nerve surgeries from 2008 to 2016 in a public hospital in the state of Pernambuco, Brazil.

\section{Materials and Methods}

The present is a retrospective study conducted within the confines of the World Medical Association Declaration of Helsinki, and approved by the Ethics and Research Committee of our institution (under number 59986616.9.0000.5208).

The present study was based on a secondary database, and data was collected from the medica records in the second half of 2017 at the Medical and Statistical Archive Service of the peripheral-nerve outpatient clinic of Hospital da Restauração, located in the city of Recife. The inclusion criteria were: medical records containing the description of the clinical diagnosis and the assessments that confirmed it (that is, magnetic resonance imaging and electromyography) from patients of any age submitted to any peripheral-nerve surgery.

The following sociodemographic and clinical data were obtained: age, gender, diagnosis, surgical technique, and the 
prevalence of the affected limbs (upper or lower) in each year. For didactic purposes, carpal tunnel syndrome was considered a unique separate group, despite being considered a compressive neuropathy. In addition, the following surgeries were grouped into microsurgery for compressive upper-limb neuropathy because they represented a very small percentage of the sample: interdigital nerve, ulnar in the Guyon canal, and median nerve of the proximal forearm.

Regarding age, normality was conducted using the Kolmogorov-Smirnov test, and the Mann-Whitney test was applied using the Statistical Paclage for the Social Sciences (SPSS, IBM Corp., Armonk, NY, US) software, version 22. For the qualitative variables, descriptive statistics were conducted and expressed as relative (percentages) and absolute frequencies ( $\mathrm{n}$ ), while for the quantitative variables, means and standard deviations were used.

\section{Results}

The sample consisted of 506 records, 268 (52.9\%) of which were from male, and 238 (47.1\%), from female patients. The age of the sample ranged from 5 to 84 years ( $41 \pm 14$ years), and was significantly different regarding gender (male patients: $35 \pm 14$ years; female patients: $48 \pm 12$ years; $p<0.01)$. The patients who sought the most care in the peripheral-nerve outpatient clinic were men aged 20 to 29 years (17\%) without health insurance. On the other hand, the age range with the highest number of patients was between 30 and 39 years (13.\% - 125 patients) (- Fig. $\mathbf{1}$ ).

Carpal tunnel syndrome was the most diagnosed lesion (38.9\% - 197), and it affected more female (34.3\% - 174) than male $(4.5 \%$ - 23$)$ patients. On the other hand, male patients were more affected by traumatic brachial plexus injury (33.2\% - 168), followed by compression of the ulnar nerve $(9.3 \%-47)$ and sural nerve tumor $(4.6 \%$ - 23) (-Table 1$)$.

An essential point of the present study is related to the large diversity of surgical techniques ( - Table 2 ). It can be noted that the diagnoses of 47 patients were listed as compression injury of the ulnar nerve on - Table 1. However, in -Table 2, only 1 submuscular transposition of the ulnar nerve was reposted. As the other 46 (17.9\%) cases underwent simple decompression, the patients were classified as microsurgery for compressive upper-limb neuropathy (-Table 2). Thus, microsurgery for compressive upper-limb neuropathy $(45.67 \%$ - 248 of all surgeries; $35.72 \%-194$ performed in female patients) followed by brachial plexus microsurgery (31.\% - 170; 29.28\% - 159 performed in male patients) were the most used surgical techniques probably because the only specialized and reference hospital in the state of Pernambuco, for these types of surgery was located in the city of Recife. It is also essential to note that some of the microneurolysis and nerve biopsies were performed due to chronic infectious leprosy disease, with the following main affected nerves: radial, median and ulnar, and facial nerves. From 2008 to 2012, there was an increase in the number of surgeries for carpal tunnel syndrome, followed by a gradual decrease in the subsequent years. On the other hand, the number of traumatic brachial plexus surgeries increased almost 5-fold from 2008 to 2016 (-Table 3). It is suggested that other hospitals in the state also absorbed these surgeries.

Given the data, it was possible to calculate the total and partial brachial plexus surgeries performed per year. Out of 18 surgeries (47\%), 11 (59\%) were for partial plexus lesion and 7 (41\%) were for whole plexus lesion. It is worth mentioning that these are medium-sized surgeries that require general anesthesia and are performed according to the demand of the service ( - Table 3 ).

As shown in - Table 4, most surgeries were performed in patients between the ages of 20 and 69 years, with the age group of 30 to 39 years presenting a higher number of surgeries. However, the age group of 20 to 29 years presented the highest number of traumatic brachial plexus injuries (61 subjects; $12 \%$ ), while those with ages between 50 and 59 years presented the highest number of cases of carpal tunnel syndrome (65 subjects; $12.8 \%$ ). The predominance of upper-limb lesions (91\%) was also observed, with males accounting for $52.75 \%$ (244), and females, 47.25 (217).

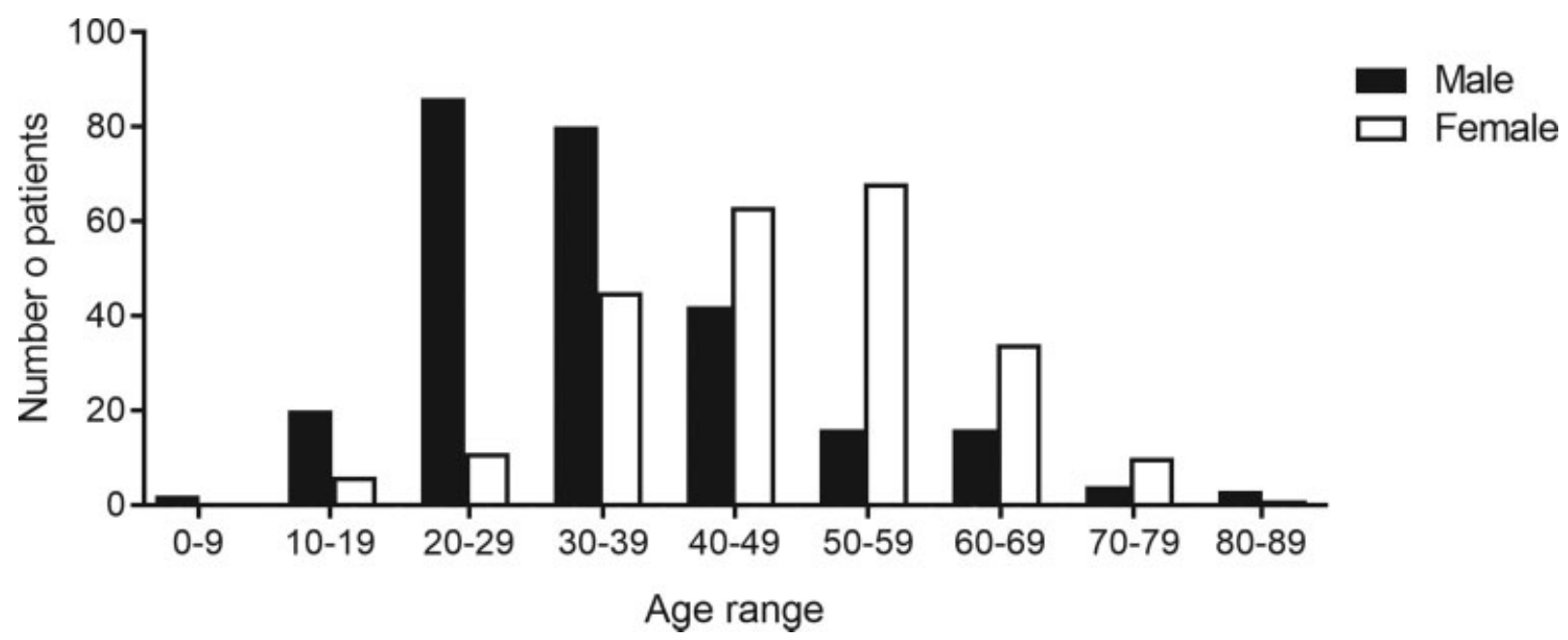

Fig. 1 Distribution by age group and gender of the surgical patients at the peripheral-nerve outpatient clinic from 2008 to 2016. 
Table 1 Diagnoses of the study sample according to gender

\begin{tabular}{|c|c|c|c|}
\hline \multirow[t]{3}{*}{ Diagnosis } & \multirow[t]{2}{*}{ ALL } & \multicolumn{2}{|l|}{ GENDER } \\
\hline & & MALE & FEMALE \\
\hline & $\mathrm{n}(\%)$ & $\mathrm{n}(\%)$ & n (\%) \\
\hline \multicolumn{4}{|l|}{ Compressive lesions } \\
\hline Carpal tunnel syndrome & $197(38.9)$ & $23(4.5)$ & $174(34.3)$ \\
\hline $\begin{array}{l}\text { Compression injury of the } \\
\text { ulnar nerve }\end{array}$ & $47(9.3)$ & $28(5.5)$ & $19(3.7)$ \\
\hline $\begin{array}{l}\text { Compression of the radial } \\
\text { nerve }\end{array}$ & $9(1.8)$ & $7(1.4)$ & $2(0.4)$ \\
\hline $\begin{array}{l}\text { Compressive neuropathy } \\
\text { of the median nerve }\end{array}$ & $2(0.4)$ & $1(0.2)$ & $1(0.2)$ \\
\hline \multicolumn{4}{|l|}{ Traumatic lesions } \\
\hline $\begin{array}{l}\text { Traumatic brachial plexus } \\
\text { injury }\end{array}$ & $168(33.2)$ & $157(31)$ & $11(2.2)$ \\
\hline $\begin{array}{l}\text { Traumatic injury of the } \\
\text { tibial nerve }\end{array}$ & $11(2.2)$ & $6(1.2)$ & $5(1)$ \\
\hline Facial nerve injury & $8(1.6)$ & $7(1.4)$ & $1(0.2)$ \\
\hline Fibular nerve injury & $8(1.6)$ & $6(1.2)$ & $2(0.4)$ \\
\hline $\begin{array}{l}\text { Traumatic injury of the } \\
\text { median nerve }\end{array}$ & $7(1.4)$ & $5(1)$ & $2(0.4)$ \\
\hline $\begin{array}{l}\text { Traumatic radial nerve } \\
\text { injury }\end{array}$ & $6(1.2)$ & $5(1)$ & $1(0.2)$ \\
\hline $\begin{array}{l}\text { Traumatic axillary nerve } \\
\text { injury }\end{array}$ & $4(0.8)$ & $2(0.4)$ & $2(0.4)$ \\
\hline Tumor of the vagus nerve & $3(0.6)$ & - & $3(0.6)$ \\
\hline $\begin{array}{l}\text { Traumatic sciatic nerve } \\
\text { injury }\end{array}$ & $2(0.4)$ & $2(0.4)$ & - \\
\hline $\begin{array}{l}\text { Traumatic injury by elec- } \\
\text { trical shock of the median } \\
\text { nerve }\end{array}$ & $1(0.2)$ & $1(0.2)$ & - \\
\hline Traumatic ulnar neuroma & $1(0.2)$ & $1(0.2)$ & - \\
\hline \multicolumn{4}{|l|}{ Neoplastic lesions } \\
\hline Sural nerve tumor & $23(4.6)$ & $13(2.6)$ & $10(2)$ \\
\hline $\begin{array}{l}\text { Median nerve tumor on } \\
\text { the forearm }\end{array}$ & $4(0.8)$ & $1(0.2)$ & $3(0.6)$ \\
\hline Accessory nerve tumor & $2(0.4)$ & $2(0.4)$ & - \\
\hline Median nerve tumor & $2(0.4)$ & - & $2(0.4)$ \\
\hline Supraclavicular lipoma & $1(0.2)$ & $1(02)$ & - \\
\hline TOTAL & 506 & $268(52.9)$ & $238(47.1)$ \\
\hline
\end{tabular}

\section{Discussion}

According to the epidemiological profile of the patients in our sample, there was a predominance of men with traumatic brachial plexus injury and women with carpal tunnel syndrome. In addition, the former affects more subjects between the ages of 20 to 39 years, while the latter, between the ages of 30 and 59 years.

According to the present study, the largest age group seeking peripheral nerve service was between 20 and 29 years (17\%). This corroborates the study performed by Flores, ${ }^{8}$ which evidenced a predominance of this age group since it is the period in which individuals are in full labor activity. This entails high costs for the health system and a significant socioeconomic impact. ${ }^{9,10}$
Table 2 Types of surgeries performed in Hospital da Restauração according to gender between the years 2008 and 2016

\begin{tabular}{|c|c|c|c|}
\hline \multirow[t]{3}{*}{ Type of Surgery } & \multirow[t]{2}{*}{ ALL } & \multicolumn{2}{|l|}{ GENDER } \\
\hline & & MALE & FEMALE \\
\hline & n (\%) & n (\%) & n (\%) \\
\hline \multicolumn{4}{|l|}{ Simple decompression } \\
\hline $\begin{array}{l}\text { Microsurgery for com- } \\
\text { pressive upper-limb } \\
\text { neuropathy }\end{array}$ & $248(45.67)$ & $54(9.94)$ & $194(35.72)$ \\
\hline $\begin{array}{l}\text { Microsurgery of the fib- } \\
\text { ular nerve }\end{array}$ & $8(1.47)$ & $6(1.10)$ & $2(0.37)$ \\
\hline \multicolumn{4}{|l|}{ Nerve transfer } \\
\hline $\begin{array}{l}\text { Brachial plexus } \\
\text { microsurgery }\end{array}$ & $170(31.3)$ & $159(29.28)$ & $11(2.2)$ \\
\hline $\begin{array}{l}\text { Motor neurotransfer for } \\
\text { the lower limbs }\end{array}$ & $4(0.73)$ & - & $4(0.73)$ \\
\hline $\begin{array}{l}\text { Neurotransference from } \\
\text { the brachial branch to an- } \\
\text { terior interosseous nerve }\end{array}$ & $2(0.37)$ & $2(0.37)$ & - \\
\hline \multicolumn{4}{|l|}{ Nerve transposition } \\
\hline $\begin{array}{l}\text { Submuscular transposi- } \\
\text { tion of the ulnar nerve }\end{array}$ & $1(0.18)$ & $1(0.18)$ & - \\
\hline \multicolumn{4}{|l|}{ Biopsy } \\
\hline $\begin{array}{l}\text { Sural nerve biopsy for } \\
\text { diagnosis }\end{array}$ & $29(5.34)$ & $19(3.49)$ & $10(1.84)$ \\
\hline $\begin{array}{l}\text { Ulnar dorsal cutaneous } \\
\text { nerve biopsy for } \\
\text { diagnosis }\end{array}$ & $25(4.60)$ & $8(1.47)$ & $17(3.4)$ \\
\hline \multicolumn{4}{|l|}{ External neurolysis } \\
\hline $\begin{array}{l}\text { Microneurolysis of the } \\
\text { radial nerve }\end{array}$ & $15(2.76)$ & $15(2.76)$ & - \\
\hline $\begin{array}{l}\text { Microneurolysis of the } \\
\text { median and ulnar nerves }\end{array}$ & $9(1.65)$ & $8(1.47)$ & $1(0.18)$ \\
\hline $\begin{array}{l}\text { Femoral nerve } \\
\text { microneurolysis }\end{array}$ & $2(0.37)$ & - & $2(0.37)$ \\
\hline $\begin{array}{l}\text { Brachial plexus } \\
\text { microneurolysis }\end{array}$ & $1(0.18)$ & $1(0.18)$ & - \\
\hline \multicolumn{4}{|l|}{ Tumor resection } \\
\hline $\begin{array}{l}\text { Microsurgery for median } \\
\text { nerve tumor }\end{array}$ & $5(0.92)$ & $2(0.37)$ & $3(0.55)$ \\
\hline $\begin{array}{l}\text { Microsurgery for acces- } \\
\text { sory nerve tumor }\end{array}$ & $2(0.37)$ & $2(0.37)$ & - \\
\hline $\begin{array}{l}\text { Microsurgery for vagus } \\
\text { nerve tumor }\end{array}$ & $2(0.37)$ & - & $2(0.37)$ \\
\hline $\begin{array}{l}\text { Microsurgery for sural } \\
\text { nerve tumor by } \\
\text { schwannoma }\end{array}$ & $2(0.37)$ & $1(0.18)$ & $1(0.18)$ \\
\hline $\begin{array}{l}\text { Microsurgery for nerve } \\
\text { tumor - malignant lesion }\end{array}$ & $2(0.37)$ & - & $2(0.37)$ \\
\hline Lipoma resection & $1(0.18)$ & $1(0.18)$ & - \\
\hline $\begin{array}{l}\text { Microsurgery for brachi- } \\
\text { al plexus tumor }\end{array}$ & $1(0.18)$ & $1(0.18)$ & - \\
\hline \multicolumn{4}{|l|}{ Reconstruction with graft } \\
\hline $\begin{array}{l}\text { Reconstruction of the axil- } \\
\text { lary nerve with sural graft }\end{array}$ & $4(0.73)$ & $2(0.37)$ & $2(0.37)$ \\
\hline $\begin{array}{l}\text { Reconstruction of the ra- } \\
\text { dial nerve with sural graft }\end{array}$ & $2(0.37)$ & $1(0.18)$ & $1(0.18)$ \\
\hline $\begin{array}{l}\text { Microneurolysis of the } \\
\text { facial nerve }\end{array}$ & $8(1.47)$ & $6(1.10)$ & $2(0.37)$ \\
\hline TOTAL & 543 & $289(53.22)$ & $254(46.78)$ \\
\hline
\end{tabular}




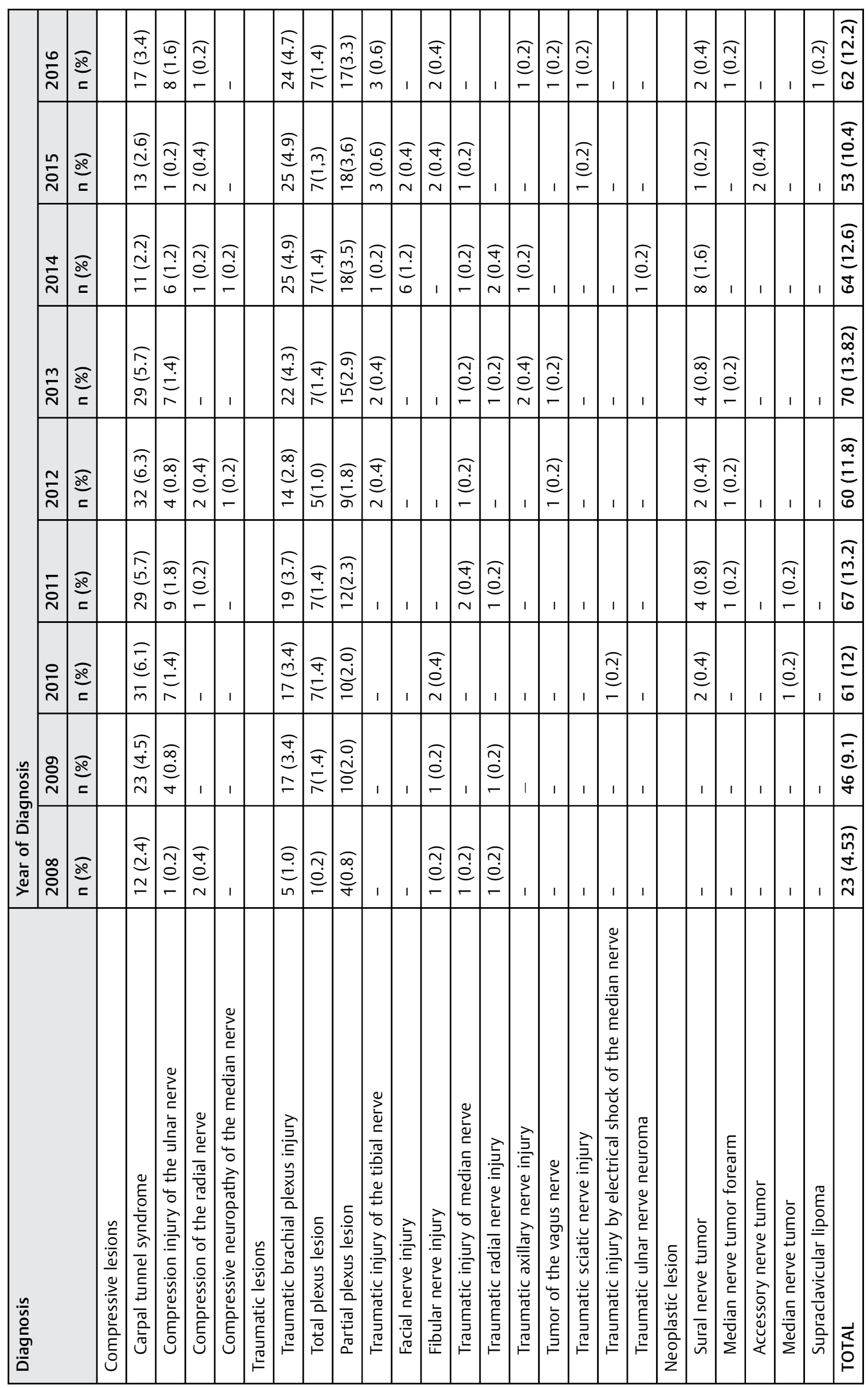




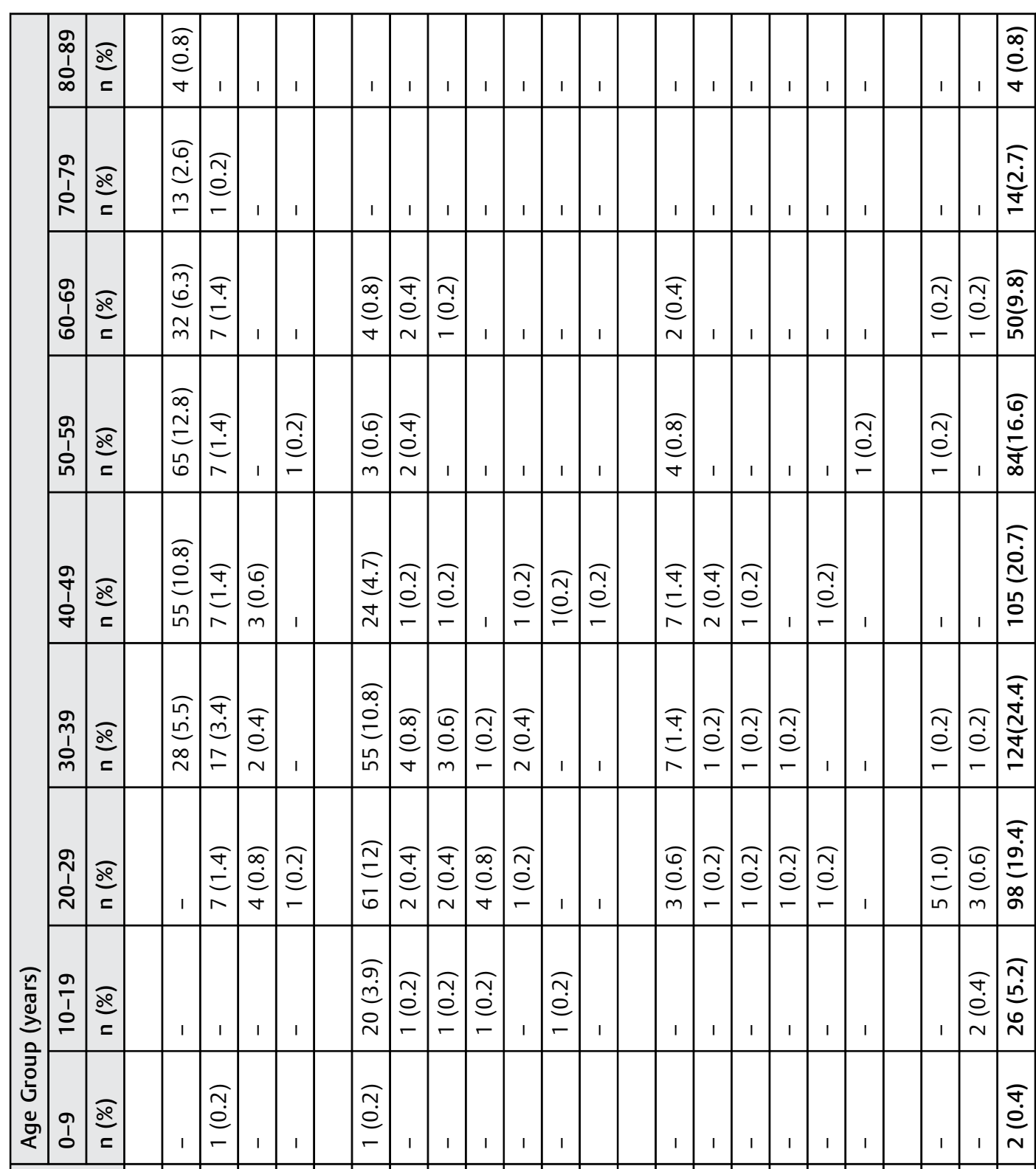

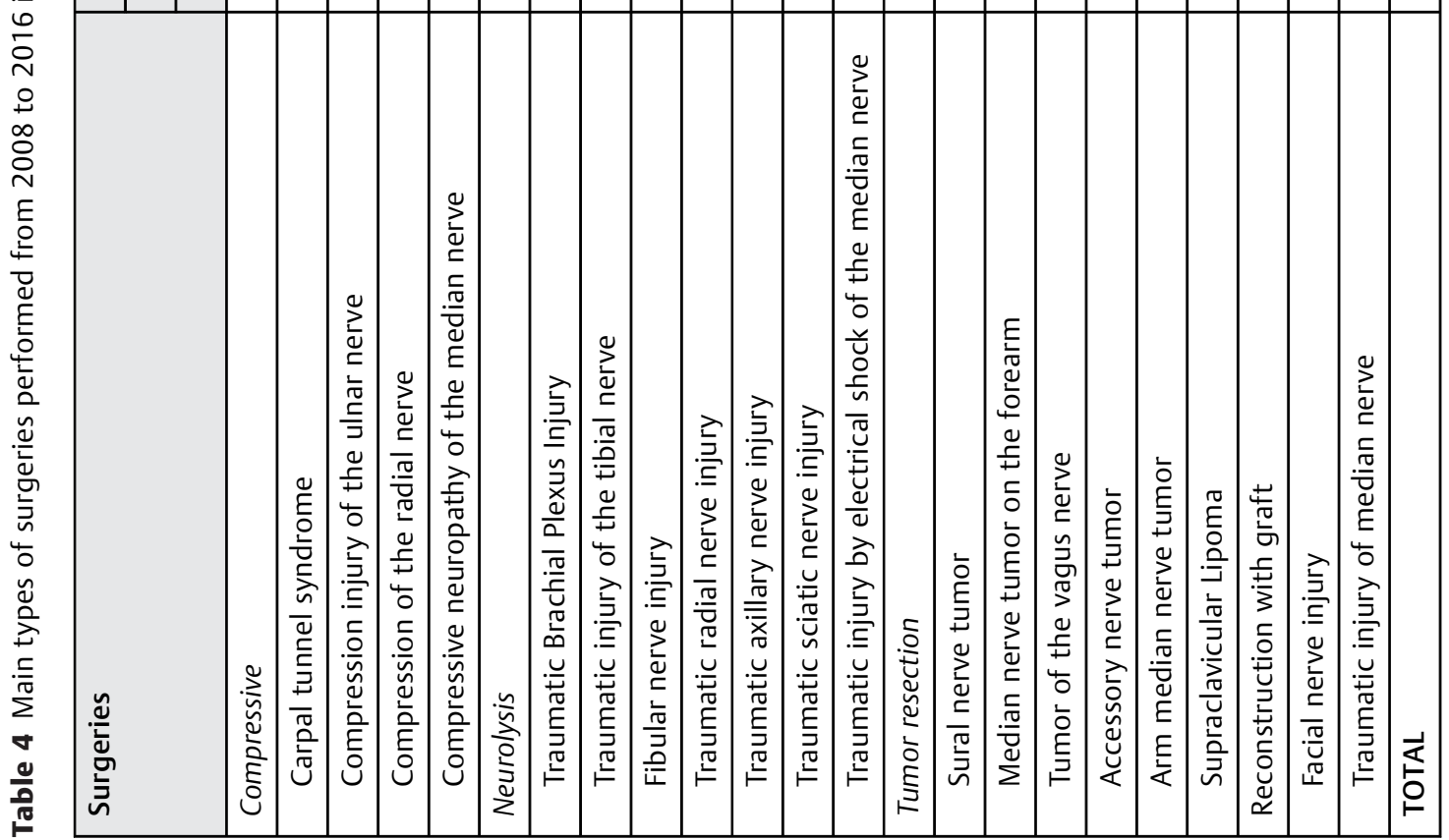


In this context, the present study showed that 157 (31\%) men had brachial plexus injury throughout the 9 years of follow-up (2008 to 2016), and that 174 (34\%) were women diagnosed with carpal tunnel syndrome. In the study by Faglioni et al., ${ }^{7}$ which was developed in the Department of Neurosurgery of Universidade de São Paulo, a higher prevalence of male patients was observed, with 384 (94.6\%) patients with brachial plexus lesions having a mean age of 28 years. Regarding women, the highest carpal tunnel syndrome prevalence was also recorded in the studies by Chammas et al. ${ }^{11}$ and Kouyoumdjian et al. ${ }^{3}$

In the study by Narakas, ${ }^{12}$ neurolysis was used 43 times in 36 patients, mainly to relieve pain, while an autologous nerve graft was used in 100 patients. The present study showed that the highest prevalence was of brachial plexus microsurgery among men $(159 ; 31 \%)$. Among the techniques used in men, we can cite the Oberlain technique, the Sonsak technique, and the phrenic nerve transfer. Among women, microsurgery for compressive neuropathy in carpal tunnel syndrome occurred 174 times (34\%).

The present study also collaborated in proving the annual increase in the number of patients with traumatic brachial plexus lesions due to the increasing rates of traffic accidents in the country, ${ }^{3,7}$ as well as a decrease in patients with carpal tunnel syndrome cared for at Hospital da Restauração, which we believe was due to the services provided at other specialized centers in the state.

\section{Conclusion}

According to the epidemiological profile outlined in the present study for surgical patients at Hospital da Restauração between 2008 and 2016, there was a predominance of young men in active working age with a diagnosis of traumatic brachial plexus injury, and of adult women diagnosed with carpal tunnel syndrome, emphasizing the predominance of upper-limb lesions.

Conflict of Interests

The authors have no conflict of interests to declare.

\section{References}

1 Patel NP, Lyon KA, Huang JH. An update-tissue engineered nerve grafts for the repair of peripheral nerve injuries. Neural Regen Res 2018;13(05):764-774

2 Siqueira MG, Martins RS. Surgical treatment of adult traumatic brachial plexus injuries: an overview. Arq Neuropsiquiatr 2011; 69(03):528-535

3 Kouyoumdjian JA, Graça CR, Ferreira VFM. Peripheral nerve injuries: A retrospective survey of 1124 cases. Neurol India 2017;65(03):551-555

4 Reichenheim MEet al. Violência e Lesões no Brasil: efeitos, avanços alcançados e desafios futuros. Saúde no Brasil 2011; 5:75-89

5 Jacobson S, Guth L. An electrophysiological study of the early stages of peripheral nerve regeneration. Exp Neurol 1965;11:48-60

6 Robinson LR. How electrodiagnosis predicts clinical outcome of focal peripheral nerve lesions. Muscle Nerve 2015;52(03):321-333

7 Faglioni W Jr, Siqueira MG, Martins RS, Heise CO, Foroni L. The epidemiology of adult traumatic brachial plexus lesions in a large metropolis. Acta Neurochir (Wien) 2014;156(05):1025-1028

8 Flores LP. Estudo epidemiológico das lesões traumáticas de plexo braquial em adultos. Arq Neuropsiquiatr 2006;64(01):88-94

9 Midha R. Epidemiology of brachial plexus injuries in a multitrauma population. Neurosurgery 1997;40(06):1182-1188, discussion 1188-1189

10 Dubuisson AS, Kline DG. Brachial plexus injury: a survey of 100 consecutive cases from a single service. Neurosurgery 2002;51 (03):673-682, discussion 682-683

11 Chammas M, Boretto J, Burmann LM, Ramos RM, Santos Neto FC, Silva JB. Síndrome do túnel do carpo - Parte I (anatomia, fisiologia, etiologia e diagnóstico). Rev Bras Ortop 2014;49(05):429-436

12 Narakas AO. The surgical treatment of traumatic brachial plexus lesions. Int Surg 1980;65(06):521-527 